\title{
ЛІТЕРАТУРОЗНАВСТВО
}

\section{ІСТОРИКО-ЛІТЕРАТУРНІ СТУДІЇ МИКОЛИ ЗЕРОВА}

\author{
ОРИСЛАВА БРИСЬКА \\ Львівський національний університет імені Івана Франка, Львів - Україна
}

\section{BADANIA HISTORYCZNO-LITERACKIE MYKOŁY ZEROWA}

\author{
ORYSEAWA BRYSKA
}

Lwowski Uniwersytet Narodowy im. Iwana Franki, Lwów - Ukraina

STRESZCZENIE. Artykuł poświęcony jest metodologii badań historycznoliterackich Mykoły Zerowa oraz wyróżnieniu pierwiastków innowacyjnych w przeglądzie literatury XIX wieku jego autorstwa. Szczególną uwagę zwraca rzetelność jego metod badawczych oraz periodyzacja literatury oparta na charakterystyce stylistycznej i gatunkowej.

\section{MYKOLA ZEROV'S STUDIES OF THE LITERATURE HISTORY}

\author{
ORYSLAVA BRYSKA \\ Ivan Franko Lviv National University, Lviv — Ukraine
}

ABSTRACT. The article outlines the methodology of the historical study of the $19^{\text {th }}$ century Ukrainian literature by MykolaZerov and highlights innovative elements of his review of the literature. The topicality of his research methods and literary achievements at the beginning of the $20^{\text {th }}$ century are pointed out. His periodization of literature as based on stylistic and genre characteristics is presented among his particularly efficient achievements.

$\mathrm{H}$ a 20-і pр. ХХ ст. припадає розквіт модернізму у світовому літературному просторі, а на українських теренах — це доба нового культурного відродження, що відкривала, здавалося б, безмежні перспективи. Однак політичний чинник розставив такі рамки, що звели нанівець усі спроби українського літератора приєднатись до дискурсу модернізму. „Здається, разом із встановленням радянської влади Україна, яка до того принаймні була європейською околицею й провінцією, де хоч із запізненням, але прищеплювалися тенденції європейського культурного розвитку й відлунювали західні дискурси, остаточно опинилась поза рамками європейського літературного процесу. < .. > 3 одного боку, вона означала певну модернізацію української нації <...>. Однак тенденція до модернізації культурного життя співіснувала з самого початку 3 паралельною тенденцією до його підпорядкування ідеології, а потім і до повного знищення"'.

\footnotetext{
${ }^{1}$ С. Па вличко, Теорія літератури, Київ 2002, с. 175-176.
} 
Літературні процеси, що відбувались у 20-і р.p. в українській літературі, відкривали шлях для ідентифікації української культури в умовах модернізованого світового контексту. Загалом орієнтація на модернізм приводить до засвоєння нових тем, стилістичних зразків, нових типів героїв i, зрештою, видозмінює саму національну культуру, що моделюється відтепер за зразком „високоі”, а не „загальнонародної літератури”.

Вагома роль у цьому процесі належить М. Зерову та його однодумцям, яких відносять до літературного напряму неокласиків: „Суто культурницька, мистецька робота Зерова й інших неокласиків ставала в радянських умовах політичною: вони були «внутрішня еміграція», тобто «троянським конем», як характеризувала їх тодішня критика, обурена найбільш тим, що неокласики, розкриваючи світові обрії та виводячи українську літературу на самостійний шлях загальномистецьких проблем, відривали ії від російськоі”’”.

Проголошені М. Зеровим принципи літературного розвитку, а це: а) переосмислення значення національної літературної спадщини та грунтовне вивчення іiі кращих здобутків; б) якісне засвоєння найкращих зразків світової літератури; в) удосконалення літературної техніки ${ }^{4},-$ визначили головні напрями його різнобічної діяльності.

В історико-літературних працях М. Зеров працює над переоцінкою української літературної традиції на тлі соціально-історичних обставин та з огляду на вимоги сучасної для нього дійсності, розставляє нові акценти в каноні національної літератури; у перекладознавчих роботах та безпосередньо через переклади значною мірою досягає другої мети - кращі зразки світової літератури 3'являються українською мовою відповідно до нових, підвищених вимог, нерідко 3 коментарями чи примітками, передмовами та статтями, що трактують цінність перекладеного твору чи групи творів певного автора, зокрема і з огляду на універсальні символи світової культури; у критичних працях розглядає питання літературної техніки.

Розпочавши як перекладач (1910), М. Зеров одночасно виступає з численними рецензіями. У 1920 -х роках він працює редактором провідних літературних видань „Книгар” та „Літературно-науковий вісник” i, окрім рецензій, пише низку передмов та наукових статей, що привертають увагу до проблем української літератури і оригінальної, і перекладної. Водночас виходять друком його історико-літературні та літературно-критичні студії Нове українське письменство (1924), До джерел (1926), укладене Українське письменство XIX cm. (1928), друкується праця Від Куліша до Винниченка (1928), де послідовно простежується становлення нової української літератури за нетрадиційною методологією та диференціюється перекладна література в українській літературній системі, що було абсолютно новаторською рисою літературознавчих праць відповідного періоду. Зважаючи на обсяг охоплених літературознавчих аспектів, їхню актуальність, новаторське осмислення та активну позицію М. Зерова щодо абсолютного оновлення української літератури як головного вияву культури, можна припускати існування неокласичної концепції літератури, що мала на меті культуротворення.

\footnotetext{
${ }^{2}$ Т. Гундорова, ПроЯвлення слова, Київ 2009, с. 108.

${ }^{3}$ С. Гординський, На переломі епох. Літературознавчі статті, огляди, есеї, рещензії, спогади, Львів 2004, с. 158-159.

${ }^{4}$ М. Зеров, Наші літературознавиі і полемісти, [в:] Його ж, Українське письменство, Київ 2003, с. 541.
} 
Тріада принципів підходу до розвитку літератури видається надзвичайно грунтовною й усеохопною, адже важливим чинником самобутності національної культури $€$ її рівноправний взаємозв'язок та перегук зі світовими тенденціями. Якщо розглядати світову літературу в сукупності найталановитіших та найпоширеніших творів як архетипну проекиію спільного універсального міфу, а національні літератури - як проекції національних міфів, то становлення національної літератури відбувається передусім через засвоєння та утвердження універсального в проекції національного 5 .

Заклик М. Зерова звертатись до джерел і світової, і національної літератури дає можливість встановити такі проекції, щоб надбудовувати нові. Його історія Нової літератури досить чітко й нетрадиційно для своєї доби розставляє акценти національних та міжнаціональних архетипів, що лягли в основу української літератури. Особливості нетрадиційного підходу М. Зерова розглянемо на прикладі його історико-літературних праць.

Новизною дослідження та основою періодизації Нової української літератури, як видається, став стиль та його зумовленість історико-культурним контекстом. Поштовхом до актуалізації такого ракурсу в процесі розгляду літератури, імовірно, стали семінари, що функціонували при Київському університеті під керівництвом В. Перетца 1904 - 1914 р.р., які М. Зеров відвідував разом із майбутніми однодумцями-неокласиками. Очевидно, саме тут сформувалась позиція М. Зерова як критика й історика літератури, сформувалась його філологічна методологія. Вона дає змогу розглядати літературу з позицій художньої форми, синонімом якої є стиль.

Головними змінними рисами стилю в різні літературні періоди вважають художні зацікавлення епохи, її динаміка й еволюція, а в широкому розумінні методологія для створення „формальної” історії літератури як духовної діяльності людини, заснованої на образному узагальненні явищ дійсності з метою художнього проникнення в ії сутність 6 . Цей факт також висвітлює джерело літературознавчої ерудиції М. Зерова, що значною мірою формувалася на працях російських дослідників, але стала надзвичайно плідною для вироблення методології аналізу тексту та формування канону літературності в українській традиції.

У чому ж полягає філологічний метод аналізу тексту? 3. Мітосик указує на два чинники з'яви та актуальності такого підходу в XIX ст.: доведена в межах філософії позитивізму суспільна потреба історико-літературних досліджень та тлумачення філології як науки про дух і культуру народу в епоху Романтизму ${ }^{8}$, Для філології всі тексти однаково цінні, вони не трактувалися як історичні джерела чи конкретні провідники змісту: вони елемент минулої культури, iї знак в сучасному світі. Історія літератури прагнула виокремити з усієї маси текстів твори літературні"'. Особливо плідними в цьому питанні праці В. Шерера $(1841-1896)^{10}$, який серед перших визначив явище наукової автономії текстів та завдання реконструювати, описати та пояснити твір.

5 М. Лановик, Теорія відносності художнього перекладу. Літературознавчі проекиії, Тернопіль 2006, с. 131.

${ }^{6}$ В. Перетц, Из лекичй по методологии, Киев 1914, с. 86-87.

${ }^{7}$ В. Дончик, Історія украӥнської літератури XX столітm, Кн. перша, Київ 1993, с. 426.

8 3. Мітосек, Теорії літературних досліджень, Сімферополь 2005, с. 97.

${ }^{9}$ Там само, с. 99.

${ }^{10}$ W. Scherer, Poetic, [in:] Heraus gegeben von Reiss G., Lubingen 1977, c. 77. 
В українському літературознавстві М. Зеров був серед тих, хто першим указав на літературний твір як самостійну одиницю системи культури, елемент, що належить до окремої ії підсистеми, який вимагає своєрідного впорядкування та аналізу на основі текстоцентричної методології. У дослідженнях М. Зерова простежуємо подібні фази філологічного аналізу, що їх виокремлюють німецькі дослідники, прибічники філологічного підходу до літератури: так звана „студія”(критика) тексту, що полягає у визначенні історії, версії та публікації твору; реконструкція тексту, тобто з'ясування його виникнення, плану, вивчення рукописів; і філологічна герменевтика, що виявляється у вивченні генези твору за допомогою зовнішніх та внутрішніх критеріїв з урахованням походження матеріалу та факти його різнорідного опрацювання, аналізі кожного мотиву 3 огляду на його походження та в зіставленні з переживаннями письменника; передбачає дослідження композиції творів, беручи до уваги існуючі зразки, простеження впливів, ретельне визначення запозичень, контрастів та паралелей, виокремлення нових та оригінальних елементів ${ }^{11}$.

Подібно до теоретиків філологічного аналізу, М. Зеров уважає своїм завданням як історика літератури вказати на культурно-історичне тло твору й визначає історичну цінність тексту через його сприйняття, наслідування та успіх у читачів. „Ураховується те, що письменник успадкував (ererbte) те, що пережив (erlebte), чого навчився (erlernte). Так у поле зацікавлень історика літератури входять не так природні чинники, як духовна історія, утілена в культурному й літературному досвіді. Це відповідає інтересам філології, що в критичній, а надто герменевтичній фазі, дошукується літературних відгомонів у тексті, повторюваних мотивів і тем, впливів і запозичень. Відповідає це також ііі описовій настанові: текст цінний як такий, потребує коментаря, а не естетичної оцінки"12.

Прикметно, що історико-літературні праці М. Зерова охоплюють власне період формування сучасної української літератури в XIX ст., коли відбувається перехід від україномовної словесності до писемності. Саме тому філологічний підхід до дослідження видається цілком логічним. Питання студії та реконструкції текстів, що з'являлися на українських теренах у цей період, були актуальними, адже становили основу для модерної літератури, яка часто викривлено сприймала чи навіть нехтувала здобутками попередніх поколінь.

Зважаючи на колонізований статус літератури, вагомими є екскурси історика в духовну історію української громади. Зокрема, характеризуючи літературу від І. Котляревського, він указує на соціальні умови, що склались у відповідний період - „соціальну базу українського культурного життя”, до якої відносить передусім „творців і споживачів літературних цінностей”, статус і стан мови та, як наслідок, особливості стилів та жанрів творів відповідного періоду, підкреслюючи їхню безпосередню взаємозумовленість.

Презентуючи період започаткування нового українського письменства, М. Зеров стверджує: „На перегоні цих 125 років значно відміняється соціальнопсихічний склад українського літератора, поширюється і збагачується коло читачів, у літературний оборот втягується велика сила ідей, одбиваючись на виборі сюжетів і дійових осіб, позначаючись на методах і засобах художнього пізнання. Письменники ставлять перед собою все ширші і ширші завдання, а залежно від них розвивають і збагачують літературну мову"13. Отже, М. Зеров

11 3. Мітосек, Зазнач. джерело, с. 98.

12 Там само, с. 99.

${ }_{13}$ М. Зеров, Нове украӥнське письменство, [в:] Його ж, Українське письменство, Київ 2003 , c. 11 . 
характеризує добу зародження Нової української літератури за такими критеріями: 1. Продуцент і споживач національної літератури - соціально-історична складова; 2. Мовний стиль; 3. Жанр літературного твору.

Указуючи на дату 1798 рік, як на час публікації перших трьох частин Перелищьованої Енеїди І. Котляревського, історик розмірковує про соціальні передумови нової літературної доби, що склалися на кілька десятків років раніше. У безпосередньому зв'язку характеризується соціальний статус читача та мови.

Аналізуючи на критичний стан української мовної політики, що опинилася в руках сільських священиків, дрібного дворянства та провінціального чиновництва, до яких передусім відносять I. Котляревського, М. Зеров визнає автора Енеїди новатором та майстром у запровадженні живої народної мови до літературного вжитку: „Народна мова дуже далека була од високих і тонких матерій, які трактувала тогочасна класична література. ...Тільки на інтермедії та на примітивній півнародній творчості різдвяних та великодніх віршів і могли спертися Котляревський та його сучасники в своїх літературних планах. Безперечно, вони почували певну ніяковість на думку про живу народну мову, як орган “високої” літератури, і тому у власній творчості спинялися на формі жартівливої, перелицьованої поеми, що не так гостро різнила 3 традицією"14.

М. Зеров переконливо доводить, що культурна традиція епохи мала здебільшого провінційний характер, а характерні ознаки читацької аудиторії переважно не надто позитивно впливали на жанрово-стилістичні характеристики текстів, що пояснює запізнілий розвиток літератури: „В українському письменстві, наслідком специфічних умов його розвитку і перш за все провінціального його характеру, травестія вийшла на сцену 3 „Пастухами” Любасевича та „Енеїдою” Котляревського на самім переломі XVIII - XIX століть. Натрапивши на традицію «студних кантів», жартівливих, півкнижних-півнародних віршів, вона придбала симпатії широкого кола читачів і - послідок псевдокласичної форми стала одним із улюблених жанрів і зосталась таким до кінця 30-х pp. <..."'15.

Другим вагомим наслідком провінційності літератури стає довготривале існування літературних стилів у часто рукописній „літературі читача”, тобто праць епігонів, які брались до творчості після прочитання певного твору.

Очевидно, з огляду на філологічну герменевтику для М. Зерова як історика літератури суспільно-історичний контекст з'яви I. Котляревського є надзвичайно важливим. Дослідник з'ясовує його походження та освіту, а також добу, коли було створено Енеїду: „Дві історичні доби виразно позначаються на ній: стара Гетьманщина, з іï старосвітським життям, якою була вона до рум'янцевських реформ $<\ldots>$, і та нова Україна, що настала з губернськими установами та поширенням на українське шляхетство жалуваної грамоти дворянству. $<\ldots>$ Сам Котляревський теж був продуктом переходової доби, - 3 живими симпатіями до колоритного минулого він сполучував уважне прислухання до нових культурних та літературних смаків, що йшли з російських центрів"16. Власне, на прикладі Енеїди М. Зеров подає характерно відмінний огляд твору української літератури, указуючи на співвідношення з оригінальним твором Вергілія та підрядником Н. Осипова, що ним користувався І. Котляревський, тобто встановлює походження: „3 перших рядків поеми Котляревського виясняється, що це твір не цілком оригінальний, що його замисел, композиція і навіть худож-

\footnotetext{
14 Там само, с. 10.

15 Там само.

${ }^{16}$ Там само, с. 21.
} 
ні засоби запозичено з чужомовного зразка. Таким зразком для Котляревського була ,Энеида" Осипова"17.

Прикметно, що питання співвідношення російської та української переробки ставало предметом окремих дослідників у добу М. Зерова, однак вагомим $€$ те, що саме він додає розвідку про походження Енеїди І. Котляревського до історії нового письменства як її складник, утверджуючи свій метод розгляду літератури за принципом епоха — ґенеза (переклад чи наслідування зразків літератури) - традиція - оригінальний твір.

Завдяки аналізу тексту, зокрема в аспекті його стилю, мовної канви і форми, М. Зеров описує способи відтворення тексту, з яким I. Котляревський працює як з оригіналом, відзначаючи його новаторство щодо наслідуваного зразка та переваги ${ }^{18}$.

До розділів про Енеїду І. Котляревського входять питання про літературний жанр, тобто окреслено ознаки травестії, визначено новаторство автора щодо віршування, текст розглянуто цілісно в плані художнього оформлення та характеристики героїв.

М. Зеров робить критичний огляд твору за названими вище критеріями, однак не применшує ваги твору для нової української літератури, указуючи на об'єктивні причини відхилення від художньої форми внаслідок різних літературних та позалітературних чинників.

М. Зеров насамперед пише про непослідовність I. Котляревського в бурлескній репрезентації богині Венери, адже на початку поеми вона має всі риси поважної дружини українського сотника, а в наступних - зображена в російському офіцерському побуті ${ }^{19}$. Однак цю рису, а також певні ознаки просодії (неприродне розміщення слів, що ускладнює читання, лапідарність ритму, явища какофонії) історик відносить до травестійного письменства, що утворює окремий літературний ряд котляревщцини, творів різного жанрового характеру, але за стилістичними особливостями суміжних за формою з Енеїдою І. Котляревського, а також окремо виділяє поняття травестійної мови: „Ця конкретність виразу, що часто-густо переходить у вульгарність, прекрасно відповідала формі травестійної поеми, з їі нахилом до карикатури, тяжінням у бік шаржовано реалістичного відтворення життя. І. Котляревський був великим майстром «травестійної» мови і на довгий час утвердив її в українській літературі"20.

Однак до явища котляревщзини М. Зеров відносить лише епігонів, тобто тих, хто копіював „зверхню сторону поеми Котляревського”, а отже, не вийшов на рівень автора-новатора. М. Зеров виділяє такі ознаки котляревщини: 1) провінційно-обивательська природа письменника; 2) грубо-гумористичне трактування народного побуту; 3) образна, конкретна, з нахилом до вульгарності $^{21}$. Таким чином, головними критеріями в розвідці періоду котляревщини $\epsilon$ соціальний статус автора, функція твору щодо зображення дійсності та мова.

У добу після І. Котляревського М. Зеров розрізняє існування старотравестійного та новотравестійного стилів. Критерієм для розрізнення слугує заміна високого стилю низьким та заміщення ознак хронотопу вихідного тексту, 3 яким працює автор. Автором, якому вдається оновити травестійний стиль, уважають I. Гулака-Артемовського. Так, до новотравестійних переробок М. Зе-

\footnotetext{
17 Там само, с. 25 .

18 Там само, с. 27.

19 Там само, с. 36 .

${ }^{20}$ Там само, с. 41.

${ }^{21}$ Там само, с. 52.
} 
ров відносить оду Горація До Любки (I, 23) та баладу Рибалка Й.-В. Гете через те, що відсутнє навмисне заниження стилю твору. Показовою щодо методології літературознавчого дослідження є об’єктивність оцінки досягнень І. ГулакаАртемовського в його травестії-перекладі оди Горація До Любки: „Ліричний вузол п'єси - спокійна ніжність поважної літньої людини <...> зоставлено непорушним, не перев'язаним на новий лад. I коли переробці бракує властивої первотворові закінченості, то самі ії хиби - необробленість вірша, необточеність фрази - надають їй своєрідної ласкавості. Ласкавість видається ще трохи грубуватою, але то тільки тому, що сама українська мова ще не досить витончена, подібна до натрудженої й шорсткої хліборобської руки"'22.

В окремому розділі М. Зеров уточнює свою тезу щодо художньої недовершеності переробок I. Гулаком-Артемовським оди Горація та балади Й.-В. Гете, зокрема, указуючи на невиробленість української поетичної мови для відтворення скомпресованого вислову та необхідної просодії характерних жанрів оди та балади ${ }^{23}$. Для обгрунтування ознак травестії-перекладу М. Зеров з'ясовує тенезу жанрово-стилістичних засобів оригіналу: „П’єса Гете - балада. Коли Гулак брався ії перекладати, баладного стилю в українській поезії ще не існувало - була народна пісня, яку допіру почали збирати й вивчати, i була травестія, що мала уже за собою деяку поетичну традицію. Гулак скористувався засобами тієї й другої <...>.”24. До періоду травестії-перекладу М. Зеров відносить спробу вільного перекладу Полтави О. Пушкіна Є. Гребінкою. На думку дослідника, цей переклад має майже всі ознаки травестійного стилю, проте Є. Гребінка наділяє переробку певними рисами власне перекладу. Така непослідовність, як уважає М. Зеров, лише зашкодила авторові досягнути мети - створити зразок вільного перекладу: „Гребінці явно не пощастило передати у своїм перекладі тон і стиль "Полтави". Брак художнього хисту, що міг би сам, власними силами, потрапити на шлях перекладу - при повній відсутності в українській літературі поетичних зразків нетравестйного типу — не дав йому змоги утворити відповідну оригіналові художню форму; а російський патріотизм провінціального гатунку $<\ldots>$ ослабив у його переказі прекрасну концепцію пушкінської поеми $<$...>. Гребінчина «Полтава» вийшла твором грубим і ординарним, безсилим привабити читача своєю ідейною стороною та художніми заслугами" 25 . У виносці до висновку М. Зеров уточнює поняття чистого перекладу, указуючи на неприйнятність у ньому ознак травестійного стилю та грубого порушення еквілінеарності.

Окреслюючи головні ознаки травестійного стилю в прозі, М. Зеров стверджує, що його поширенню сприяє передусім популярність серед читацької аудиторії ${ }^{26}$, а єдиною ознакою, що вказує на його іншокультурне походження, залишається сюжет. Дослідник аналізує спроби українських авторів цього періоду подолати ознаки травестійного стилю (зокрема йдеться про твір Я. Кухаренка Харко, запорозький кошовий, задуманий як історична поема на зразок Полтави О. Пушкіна).

Псевдокласицизм травестійної поеми та надмірно розгорнуті описи побутового плану, здійснені в бурлескному тоні, приводять М. Зерова до висновку, що саме ці ознаки прирікають поему на невдачу і призводять до невідповідності змісту й травестійної форми ${ }^{27}$.

\footnotetext{
22 Там само, с. 60.

${ }^{23}$ Там само, с. 61 .

${ }^{24}$ Там само, с. 62 .

${ }^{25}$ Там само, с. 66-67.

${ }^{26}$ Там само, с. 67.

${ }^{27}$ Там само, с. 74-75.
} 
Окремими групами історик розглядає байки та драматичні твори перш. пол. XIX ст. Жанрове розрізнення допомагає йому встановити їхню генезу та, зрештою, указує на перекладне походження цих жанрів. У загальній характеристиці, попри популярність нового літературного стилю, яким став сентименталізм, М. Зеров констатує панування псевдокласицизму, передусім під впливом російської традиції: „Розвиваючись на грунті оперет Котляревського, всі вони немов ілюструють дальший вплив не українську драматичну творчість російський «п’єс з куплетами» і слідом за ними відносяться до давнього, ще псевдокласичного літературного жанру (значно підсентименталеного в дусі літературної моди)"'28.

Аналізуючи байку, М. Зеров доводить паралельно з російським і польське походження сюжетів значної частини творів, зокрема він пише про лектора польської мови при Харківському університеті Ігнатія Красіцького. Л. Боровиковського, учня П. Гулака-Артемовського, історик вирізняє серед байкарів, яким удається запозичити не лише сюжети, а й форму „байки-приказки”.

Російський вплив на українських байкарів, зокрема запозичення з I. Крилова, М. Зеров простежує у творчості І. Білецького-Носенка та С. Гребінки. М. Зеров зважає на їхню генезу, розрізняючи мандрівні байкарські сюжети, а також дидактичні оповідання 3 античної міфології, історичні анекдоти та українські перекази й легенди. Мову байок він розглядає в аспекті дохідливості до читача: „Мова в них сіра, неправильна, безбарвна, хоч і прикрашена подекуди хорошими старовинними словами; характеристики дійових осіб, надто зі звірячого царства, мало пов'язані $з$ народними уявленнями і тому невиразні, бліді; велика кількість класичних греко-латинських імен (боги, герої, географічні назви) — наведені часто-густо без потреби і тільки обтяжують оповідання"29.

М. Зеров наголошує на вагомому внеску Є. Гребінки в розвиток української байки, указуючи на свідоме порушення ним шаблонної форми: „Безпосереднім чуттям художника Гребінка зрозумів усю штучність байки, непристосованість iï до оформлювання вражень біжучого життя, а тому й став на шлях послідовного руйнування цієї умовної і тісної форми"зо. Передусім ідеться про розширення оповідання декоративними деталями, насичення їх інтонаційною різноманітністю, талановите впровадження оповідача, виробленість і характерність мови, що вбирає в себе народні прислів'я та приповідки, широкий побутовий малюнок. Жанр байки стає предметом окремого дослідження М. Зерова, де він простежує його генезу та еволюцію в українській літературі за схемою, подібною до Нового українського письменства, тобто від переробки iii до перекладу в оригінальну байку. М. Зеров акцентує на тому, що байкарська творчість Л. Глібова розширює межі жанру та приводить його до утворення нових, зокрема побутової новели, інтимної елегії, дитячої пісні та ін.

Важливо, що провідним чинником таких жанротвірних девіацій М. Зеров уважає зміни соціального характеру - вимоги аудиторії, що приводять автора до іншого цільового читача, а саме - дітей: „У більшості ж випадків, маючи на увазі свою неповнолітню аудиторію, він примушений був звертати головну увагу на самоінертність та на естетичну вимовність оповідного матеріалу, оздоблювати його порівняннями, технічними термінами, розмаїто підібраними realia $<\ldots>$. Діалог збагачується так само примовками, метафорами,

\footnotetext{
${ }^{28}$ Там само, с. 79 .

29 Там само, с. 87.

${ }^{30}$ Там само, с. 88-89.
} 
ідіоматизмами. Докладність оповідання, детальність експозиції < ..> стає правилом. Байка намагається стати новелкою"з1.

Серед прозових жанрів, що сформувались у процесі еволюції нової української літератури, особливого трактування набули повісті Г. КвіткиОснов'яненка. Характеризуючи його творчість, М. Зеров називає два джерела новаторських рис його творчості - літературні та фольклорні. Соціальне походження автора посприяло його знайомству $з$ іншомовними зразками стилю та стало вирішальним, на думку М. Зерова, у виборі ним літературного методу, яким став сентименталізм, а українська культура, що мала міцну народнопісенну традицію, надавала багатий мовний матеріал та надовго закріпила цей напрям в українській літературі ${ }^{32}$.

Саме критерій мови у високомайстерній поетичній формі, що тісно межувала 3 українською народнопісенною традицією та національною ідеєю, на думку М. Зерова, якісно вирізняє й відокремлює від усієї існуючої на той час писемності творчий доробок Тараса Шевченка. Творча постать Кобзаря в літературознавчому контексті періоду М. Зерова трактувалась неоднозначно, тривалий час побутувала думка про несприйняття неокласиками народницької творчості поета.

Однак, на нашу думку, власне історико-літературні праці М. Зерова свідчать про його високе поцінування творчості Т. Шевченка та сприяння утвердженню канонічності національного поета. М. Зеров ретельно аналізує тексти поезій Т. Шевченка за ідейно-тематичним, стилістичними та жанровими характеристиками, простежує їхню генезу, чинник джерельної бази, вказує на широку популярність та актуальність його творчості серед суспільства.

У ранньому періоді його творчості критик виокремив три групи за жанровими ознаками: а) дума з історичним, політичним або й персональним змістом; б) балада; в) байронічна ліро-епічна повість. При цьому, з огляду на усталену традицію жанру балади М. Зеров відзначає послаблення іiі сюжетного укладу, досліджує впливи польської та російської літературної традиції.

Аналізуючи байронічну поему у творчості Т. Шевченка, зокрема на прикладі Катерини, дослідник визначає місце твору в еволюції жанру. У характеристиці генези жанрово-стилістичних та ідейно-тематичних ознак поеми Сон М. Зеров зводить дослідження до встановлення та зіставлення текстів, що слугували джерельною базою для творчого генія: „Отже, російські радикальні настрої 30 - 40-х років 3 культом декабризму, впливи польської революційної мислі й Міцкевича, пильне читання „Истории Руссов” — таку складну генеалогію мають думки і освітлення Шевченкової поеми"з3. Формі поезії Т. Шевченка та його прозовим творам М. Зеров присвячує окремі розділи, де висловлює свою безсторонню позицію.

Отже, стилі та жанри, а також їхня соціальна зумовленість стають ключовими поняттями, завдяки яким М. Зеров трактує розвиток української літератури. Такий підхід дає можливість визначити етапи формування автономності української національної літератури, іiі відокремлення від літератури колонізатора: період травестії, переспіву, власне перекладу та оригінального письменства.

Одночасно історик простежує ознаки письменницької продукції в ракурсі загальносвітових літературних тенденцій, виокремлюючи періоди псевдокла-

${ }^{31}$ Там само, с. 951.

32 Там само, с. 92.

${ }_{33}^{3}$ М. Зеро в, Твори, у 2 томах, Київ 1990, т. 2: Історико-літературні та літературознавyi npaui, c. 168. 
сицизму, романтизму, сентименталізму та неоромантизму в українському письменстві, чим намагається ввести його до загальносвітового культурного дискурсу.

Філологічно-герменевтичне прочитання історії літератури ХІХ ст. виявилося новаторським і актуальним, адже нарешті предметом дослідження стає текст і не винятково в його естетичному ключі, а саме у функціонально-стилістичному 3 урахуванням соціального чинника. Адже презентовано нову систему літературних цінностей та міцний фундамент для надбудови української модерної літератури за чіткими орієнтирами та своєрідними нормами з огляду на соціальні обставини, стиль тексту та його мовне розмаїття.

Сьогодні чимало дослідників згадують доробок М. Зерова в історичному літературознавстві, але методологічна база його праць, як видається, все ще потребує більш грунтовного дослідження на предмет суголосся з сучасними для його доби літературознавчими течіями у світовому контексті, адже чимало 3 них не втратили актуальності й сьогодні та могли б стати для сучасного літературознавця плідним джерелом ідей. 